\title{
FOCUS On Fiction: Your Online Companion To K-12 Literature
}

\author{
Jill Midolo \\ Curriculum Officer \\ Curriculum Materials Information Services \\ Department of Education and Training \\ WESTERN AUSTRALIA
}

\begin{abstract}
Focus on Fiction <www.eddept.wa.edu.au/cmis/eval/fiction> is widely respected throughout Australia as a comprehensive online gateway to children's literature. This workshop session will investigate its content and the ways it can be used to create class or library programs that integrate the latest online technologies into literature-based programmes. NB: This paper provides background information for a workshop session that will be presented through a webpage.
\end{abstract}

This conference theme centres on 'the power of story to change lives, to empower, to unite, to explore the internal and external world, and how school libraries can play a crucial role in developing readers'.

Foc'us on Fiction, the Curriculum Materials Information Services website aims to help teachers to do utilise the power of story and develop readers within Western Australia and Australia. Our concentration is broader than libraries, but we know from experience that our main users are teacher librarians.

\section{Why a website? Why fiction?}

Initially, in 1996, we saw the fiction section of our website as a support for our print journal Fiction Focus, which is a respected journal that reviews fiction for teenagers. However, we soon moved beyond this, starting an online book club in 1997 and then the Authors and Illustrators section to support the book club. The book club was too successful; we did not have the staff to maintain it. With the first major remodelling of the website at the end of 1998, we decided on selecting the sections almost exactly as they appear today:

- Authors and Illustrators

- Children's Book Week

- Book Awards

- In the Classroom

- Which Book?

- Keeping Informed 
Content in these sections of the site focuses on providing support for literature programs: books to read; background about authors; classroom applications of online resources suitable for literature programs; and professional development. As it happened, the things we chose to include were the same as those selected by the Eric Clearinghouse on Reading, English and Communication and reported in an ERIC Digest (Lu, Mei-Yu 1999). This Digest identified four main types of materials teachers were looking for as: "(1) literature-hased lesson plans, (2) aids to materials selection. (3) online publications for and by K-12 students, and (4) professional development resources".

Since this 1999 Eric Digest, a number of other Australian and international reports on children's reading continue to shape the support service we offer for teachers.

\section{Research evidence 2000 - 2004}

I would like to quote five pieces of research from this period that have influenced our conviction that lifelong reading for pleasure is critical to improving students' reading competence and the continued enhancement of the Foctus on Fiction website.

\section{Young Australians reading: From keen to reluctant readers (2001)}

Woolcott Research Pty Ltd prepared this report for the Australian Centre for Youth Literature and the Audience and Market Division of the Australia Council. Some of their key findings included that:

- $74 \%$ of all 10-18 year olds claim to like reading to some extent

- $76 \%$ of primary and $46 \%$ of secondary students read 'every few days'

- $64 \%$ would like to read more

- $56 \%$ of primary and $78 \%$ of secondary students found required reading at school 'boring'

- girls are more likely to say they enjoy reading than boys ( $86 \%$ vs $70 \%$ )

- fewer than $20 \%$ of the target group consider their school or public libraries inviting or able to meet their recreational reading needs

These are worrying statistics, especially the last, for people such as ourselves who promote reading as an important activity for students and assume that school and public libraries are where they will find support for their reading.

\section{Reading for change: Performance and engagement across countries. Executive Summary (2002)}

The 2000 OECD Programme for International Student Assessment (PISA) survey of 15-year-olds' reading literacy performance brought out some interesting points about student reading, particularly in relation to engagement in reading. I have 
italicised parts of the statement I think are of particular relevance to the service we provide for teachers:

These results show unequivocally that improvement in reading literacy performance relies not just on improving student cognitive skills but also on increasing their engagement in reading. Students who have better educated parents in hetter jobs, and who have books and other resources in their homes, have more chances of coming to school more engaged in reading. and of entering into a virtuous circle of increasing reading interest and improving reading performance. Yet not all of engaged readers come from privileged homes, and those from more modest backgrounds who read regularly and feel positive about it are better readers than people with home advantages but weaker reading engagement. This strongly suggests that there is much that schools can do to bring students into this virtuous circle, regardless of their home hackground. Since cognitive skills and reading motivation are mutually reinforcing in this process, rather than being alternatives, schools need to address both simultaneously: Just as it can be ineffective to give didactic instruction in reading strategies to a class of students who have little interest, so it is misguided to set reading tasks that attract the interest of young people but do nothing to improve their cognitive skills. The emergence at relatively early ages of for example, gender differences in reading indicate that the task of engaging students needs to start early on in education and continue through secondary school. (p.19)

Australian students as a whole did very well on this survey of 31 countries. Australia is one group of twelve countries (Australia, Austria, Belgium, Canada, Finland, Iceland, Ireland, Japan, Korea, New Zealand, Sweden and the United Kingdom) with mean scores on the combined reading literacy scale that are significantly above the OECD mean.

However, there was some disturbing news as regards some Australian students' engagement with reading in the accompanying Australian report (emphasis added):

Students in the Australian Capital Territory achieved the highest Australian result on the reading engagement index, significantly higher than the OECD average, while students in Victoria, Queensland and Western Australia achieved the lowest Australian results on this index, significantly lower than the OECD average. (p/30) PISA 2000). Australian report)

These results tie in with those of the Australian Centre for Youth Literature and appear to suggest that school teachers and teacher librarians are not always making a significant impact on young Australian teenage students' engagement with reading.

NOTE: Australian students did not take part in the Progress in International Reading Literacy Study (PIRLS 2001) Study, which surveyed 10-year-old students in 35 countries. 


\section{Student learning through Ohio School Libraries: The Ohio Research Study (2003)}

This study, undertaken by Dr. Ross Todd and Dr. Carol Kuhlthau (Todd, 2003) for the Ohio Educational Library Media Association (OELMA), has thrown up some interesting findings on the role of the school library in relation to developing reading, especially for secondary students.

In the article 13,000 Kids Can't Be Wrong by Debra Lau Whelan, (2004), Todd was asked whether there were any surprises in the study. His reply was:

Students ranked general reading interests as sixth fin order of importance in a school library. This raises some interesting questions, becalse for decades we've said that the school library is the place for reading enrichment and encouragement and for helping kids become better writers. It's clear that libraries still do so, hut it's a challenge for school librarians to do that better. It's obvious that school libraries help kids with general reading interests, but kids perceive help in other. areas, such as computer technology, as more important.

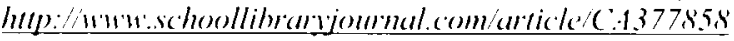

More specifically, in his PowerPoint presentation, Be still and listen to the voices, at the School Library Association of Victoria conference From Research to Practice in March 2004, Todd told participants that research tells us that an effective school library is one that: "has a vibrant literature / reading program for academic achievement and personal enjoyment and enrichment'.

However, he also noted that only $76.71 \%$ of students agreed that 'The school library has helped me enjoy reading more" (Question 54 in the OELMA Study) and $74.42 \%$ agreed that 'The school library has helped me get better at reading' (Question 53 in the OELMA Study) (Todd, 2004).

These percentages are very low when compared with the $96.84 \%$ of students who agreed that 'The school library has helped me know the different steps in finding and using information' (Question 11 in the OELMA Study).

\section{Zero to six: Electronic media in the lives of infants, toddlers and pre- schoolers (2003)}

This report (Rideout, Vandewater \& Wartella, 2003) published online in the US by the widely respected Kaiser Foundation found that:

Children six and under spend an average of two hours a day using screen media ( 1 hour 58 minutes), about the same amount of time they spend playing outside ( 2 hours 01 minutes), double the amount of time they listen to music (59 minutes) and well over the amount they spend reading or being read to (39 minutes). http:/www.kff.org/entmedia/entmedial(02803nr.efm

I would suspect that Australian children are also starting school having spent far more time with TV, videos and computers than with books, and a recent 
Australian Bureau of Statistics report certainly shows this pervasiveness of TV over books in the reported leisure activities of children aged $5-14$ years.

\section{Children's participation in cultural and leisure activities, Australia (2004)}

This recent Australian Bureau of Statistics report shows that:

Watching television or videos was the most popular of all the selected activities and children spent an average 22 hours over a school fortnight watching television or videos. Reading for pleasure, and playing electronic or computer games were also popular leisure activities for children. Participants in these activities spent an average of 8 hours over a school fortnight involved in each of these activities.

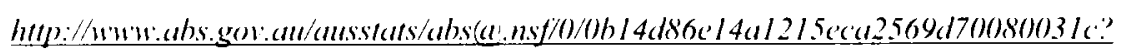
OpenDocument

At CMIS, we have used findings from these reports to amend and expand what we offer for teachers on our Focus on Fiction website. We include a range of Information and Communication Technologies (Audio, video, multimedia, Internet) because these are formats that appeal to students and can enrich their understanding and enjoyment of literature.

Most recently, as a result of reading Doiron's 2003 article 'Motivating the Lifelong Reading Habit Through a Balanced Use of Children's Information Books' in the IASL journal, School Libraries Worldwide, we are considering establishing a major section on developing extended leisure reading using nonfiction.

\section{What is in Focus on Fiction - and - how can it help you in your school/library/classroom?}

I will now look in detail at each section of Focus on Fiction and outline the content of each. The following screen dumps provide some sense of this content:

Authors and illustrators:

http:/www.eddept.wa.edu.au/cmis/eval/fiction/authors/

Contains information about authors and illustrators of children's and young adult literature and links to those that have their own homepages. Preference is given to Australians but notable international authors and illustrators are continually being added.

\section{Children's Book Week}

http://www.eddept.wa.edu.au/cmis/eval/fiction/bookweek/

This section changes each year to support the Children's Book Council of Australia's annual Book Week and Awards. This year, the Book Week theme is 'Doorways' and one of our staff has prepared ideas and resources for the theme for each of the WA Phases of Development. Teachers can also access the complete 
CBCA Shortlist and follow links to teaching notes, activities, author and illustrator information, reviews, bibliographic details and book covers.

\section{Book Awards}

http: www eddept.watedu.atu cmis eval tiction anards:

Contains information about the major Australian and international book awards for children's and young adult literature. The awards are all designed to promote an interest in reading and to encourage quality writing. illustration and publishing in the field. Included are both literary awards judged by adults, and children's choice awards, in which children vote for their favourite title. There are also links to major literary awards for adults, which may interest senior literature students and teachers.

\section{In the Classroom}

hup:/ www.eddept.wa.edu.iu/cmis/eval/fiction/classroom/

This section is aimed at teachers planning literature-based units for their students. It contains suggested strategies for utilising fiction to help students achieve learning outcomes; ideas for motivating students to read more widely; and links to general fiction-related resources, which are useful starting points for curriculum planning.

\section{Which Book?}

hitp:/ /www.eddept.wa.edu.aucmis/eval/iction whichbook/

Searching for a book to recommend to an avid or reluctant reader? Compiling a list of fiction to support curriculum themes? Wondering what to read next? Looking for outstanding books not to be missed? Which Book? contains reviews and bibliographic details of books taken from the CMIS publications, Primary Focus Fiction and Fiction Focus: New Titles For Teenagers. Teachers, teacher librarians or other professionals in the field of children's literature have written the appraisals listed in these publications. Novels, early chapter books, picture books and audio books relevant to children and adolescents are included.

\section{Keeping Informed: htpp:/www.eddept.wa.edu.au/cmis/eval/iction information}

Here you will find reading to keep you up-to-date with children's and young adult fiction, current research into reading and literacy, plus information about conferences and literature courses. NB. The page from which this presentation is run is in this section: hun:/www.eddept.wa.edu.alu/cmis eval tiction information iaslslat

\section{Final Comments}

When enriching your literature program in this online world, look at what can you do now that is better and/or different from what you could do pre-Internet [WWW and email]. Some of this will relate to speed and effectiveness rather than 
what you do - others will be things you could never have done without these new tools. For example:

- contact/correspond with authors by email and get almost instantaneous responses

- find out about books, authors, awards .... as they are published

- lesson plans from teachers throughout the world

- children talk to others about books in real time in widely different locations - clubs, literature circles, book raps, blogs

- talk to other teachers and share ideas in email lists, bulletin boards, chat rooms ...

You could use Google to search for all of these things - but a better way - is to use the resources we have already searched out for you on the CMIS Focus on Fiction website: http:/www.eddept.wa.edu.au/cmis/eval/fiction

\section{References}

Australian Bureau of Statistics 2004, Children's Participation in C'ultural and Leisure Activitics. Australia, Commonwealth of Australia, Belconnen, ACT, available online at http://www.abs.gov.atu/ausstats/abs(d.ns\%/(0/0)bl4d86el4al215ecal2569d700800310?O penDocument

Australian Centre for Youth Literature 2001, Young Australiams. Reading: From keen to reluctant readers, Prepared by Woolcott Research Pty Lid for the Australian Centre for Youth Literature and the Audience and Market Division of the Australia Council, Australian Centre for Youth Literature, Melbourne

Doiron. Ray 2003. 'Motivating the Lifelong Reading Habit Through a Balanced Use of Children's Information Books', School Lihruries Worldwick, IASL vol. 9, no. 1 2003, pp. 39-49

Lu. Mei-Yu 1999, Online Resenuress for K-12 Teachers: (Children's and Adelescent Literature. ERIC Digest D/49, Eric Clearinghouse on Reading, English and Communication. Bloomington. Indiana, available online at http://www.ericfacility.nel/ericdigests/ed $436009 \mathrm{html}$

Mullis, I.V.S.. Martin, M.O., Gonzalez, E.J.. \& Kennedy. A.M. 2003, PIRLS 200I International Report: IEA's Study of Reading Literacy Achicvement in Primary Schools, A report of the Progress in International Reading Literacy Study (PIRLS). Chestnut Hill, Massachusetts, available online at http://imss.be.edu/pirls200) i/PIRLS2001 Pubs_IR.html

Organisation for Economic Co-Operation and Development (20)2). Reading for ChangerPerformemere and Engagement Across Commiries, 2000 OECD Programme for International Student Assessment (PISA), Paris, France, available online at Full Paper http://www.pisa.oecd.org/Docs/Download/reading for change.pdf Exec. Summary http://www.pisa.oecd.org/Docs/Download/ReadingExeSummary.pdf Australian paper hı!p:/www.pisa.oecd.org/NatReports/PISA2000/Australianatrep.pdf

Rideout. Victoria J, Vandewater, Elizabeth A. Wartella. Ellen A. 2003. Zero to Six: Electronic Media in the Lives of Infants, Toddlers and Preschoolers, Kaiser Family Foundation, Menlo Park, California, ancuilahle online at htlp://www.kff.org/entmedia/3378.cfm

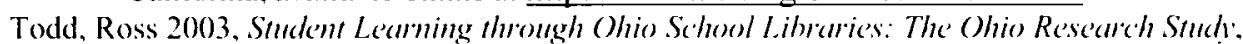
Undertaken by Dr. Ross Todd and Dr. (arol Kulithau for the Ohio Educational Library Media Association (OELMA), available online at http://www.oclma.org/StudentLearning/SLFindings.asp

Todd, Ross 2004, Be still and listen to the voices, PowerPoint presentation at the School Library Association of Victoria conference From Research to Practice March 2004, available online at htp://www.slav.schools.net.au/ppoints/Todd_1_2004.ppt

Whelan. Debra Lau 2004, '13,000 Kids Can't Be Wrong', School Libreny Jommal. Issue 2. February 2004, available online at hltp://www.schoollibraryjournal.com/article/CA377858 


\section{Author Note}

Jill Midolo has been a teacher librarian in WA secondary schools since 1969 . For the past 10 years she has worked as a Curriculum Officer at Curriculum Materials Information Services, where her main roles have included editor of Fiction Focus and Technology Focus, and manager of the CMIS Evaluation website. 